\title{
Prinsip-prinsip Islam Tentang Demokrasi : Studi Pemikiran Nurcholish Madjid Tahun 1970-2005
}

\author{
Akmal Hawi \\ Universitas Islam Negeri Raden Fatah Palembang \\ akmalhawi_uin@radenfatah.ac.id
}

\begin{abstract}
This article is a summary of research results written using descriptive and holistic methods. By reviewing primary and secondary sources to obtain accurate and clear data that contains: Islamic principles of democracy in the struggle of Nurcholish Madjid, Islamic Principles about Democracy in Learning Applying Islamic Principles about democracy in Indonesia. Democracy requires real effort from every citizen and its supporting devices, namely a conducive culture as a manifestation of a society's thinking and design to create democracy as a view of life in the country both by the people and the government. The regularity of the background, the importance of this article is discussed. This article will discuss more about discussing Nurcholish Madjid about Islam and democracy.
\end{abstract}

Keywords: Islam, Democracy, Nurcholish Madjid

\begin{abstract}
Abstrak
Artikel ini merupakan rangkuman hasil penelitian penulis dengan menggunakan metode deskriptif dan holistik. Dengan mengkaji sumber primer dan sekunder untuk memperoleh data yang akurat dan jelas yang meliputi : prinsip-prinsip Islam tentang demokrasi dalam pemikiran Nurcholish Madjid, implementasi prinsip-prinsip islam tentang demokrasi dalam pemikiran Nurcholish Madjid pada percaturan politik di indonesia, serta faktor pendukung dan penghambat dalam menerapkan prinsip-prinsip Islam tentang demokrasi di Indonesia. Demokrasi memerlukan usaha nyata dari setiap warga dan perangkat pendukungnya, yaitu budaya yang kondusif sebagai manifestasi dari suatu kerangka berpikir dan rancangan masyarakat untuk menjadikan demokrasi sebagai pandangan hidup dalam bernegara baik oleh rakyat maupun pemerintah. Keterhubungan inilah yang menjadi latar, pentingnya artikel ini dibahas. Artikel ini akan membahas lebih lanjut tentang pemikiran Nurcholish Madjid tentang Islam dan demokrasi.
\end{abstract}

Kata Kunci : Islam, Demokrasi, Nurcholish Madjid

\section{Pendahuluan}

Menurut Nurcholish Madjid (1982, hlm. 46), demokrasi yang dirumuskan "sekali untuk selamanya", sehingga tidak memberikan ruang gerak bagi adanya perkembangan dan perubahan, sesungguhnya bukan demokrasi, melainkan kediktatoran. Pengalaman menunjukkan bahwa begitu orang mencoba merumuskan demokrasi sekali untuk selamanya maka ia berubah menjadi idiologi tertutup. Padahal, demokrasi memerlukan dan memang termasuk idiologi terbuka, yaitu sebuah idiologi yang respek bagi adanya perubahan dan perkembangan melalui eksperimentasi bersama. Justru kekuatan demokrasi terletak dalam sistem bahwa ia mampu, melalui dinamika internnya sendiri, mengadakan 
kritik ke dalam sekaligus melakukan perbaikan-perbaikan berdasarkan prinsip keterbukaan dan kesempatan untuk bereksperimen. Kedua prinsip ini merupakan ruh demokrasi yang paling sentral.

Demokrasi memerlukan usaha nyata dari setiap warga dan perangkat pendukungnya, yaitu budaya yang kondusif sebagai manifestasi dari suatu kerangka berpikir dan rancangan masyarakat untuk menjadikan demokrasi sebagai pandangan hidup dalam kehidupan bernegara baik oleh rakyat maupun pemerintah. Menurut Nurcholish Madjid (1987, hlm.22), demokrasi bukanlah kata benda, tetapi lebih merupakan kata kerja yang mengandung makna sebagai proses dinamis. Karena itu demokrasi harus diupayakan dan dibiasakan dalam kehidupan sehari-hari. Demokrasi dalam kerangka di atas berarti sebuah proses melaksankan nilai-nilai civility (keadaban) dalam bernegara dan bermasyarakat.

Oleh karenanya, Nurcholish Madjid menawarkan konsep Islamo-demokrasi, yang menempatkan kehadiran Tuhan dalam demokrasi. Konsep Islamo-demokrasi ini berbeda dengan konsep theo demokrasi yang pernah dikembangkan oleh Maududi. Bukan saja pandangan Nurcholish Madjid yang menjadi Islam sebagai sumber etika asasi bagi penyelenggaraan negara, tetapi juga konsep Islam-demokrasi tetap menempatkan rakyat sebagai pemegang kedaulatan. Sedangkan teo-demokrasi berdasarkan keyakinan bahwa Islam menyediakan secara lengkap, termasuk teknis penyelenggaraan negara dan bahwa kedaulatan berada di tangan Tuhan. Sebagai pemikir dan teolog pemikiran demokrasi Nurcholish Madjid mampu mempengaruhi wacana publik, meskipun pada awalnya mendapatkan tantangan dari berbagai pihak. Gagasan kontroversial Nurcholish Madjid akhirnya diterima bahkan menjadi wacana besar demokratisasi di Indonesia.

Berikut ini ada 6 norma demokratis yang dibutuhkan oleh tatanan masyarakat yang dikemukakan oleh Nurcholish Madjid (1992, hlm. 35-36) berikut ini:

1. Kesadaran akan pluralisme. Kesadaran atas kemajemukan membutuhkan tanggapan dan sikap positif secara aktif. Pengakuan kenyataan perbedaan harus diwujudkan dalam perilaku menghargai beragam pandangan orang lain. Norma ini dapat mencegah munculnya sikap dan pandangan hegemoni mayoritas dan tirani minoritas. Kenyataan alamiah kemajemukan Indonesia dapat dijadikan modal potensial bagi masa depan demokrasi Indonesia.

2. Musyawarah. Musyawarah menuntut keinsyafan dan kedewasaan warga negara untuk tulus menerima negosiasi dan kompromi-kompromi sosial dan politik secara damai dan bebas dalam setiap keputusan bersama. Dalam bermusyawarah, setiap orang harus menerima kemungkinan terjadinya "partial functioning of ideals" yaitu belum tentu seluruh pikiran seseorang atau kelompok diterima dan dilaksanakan sepenuhnya. Konsekuensinya adalah kesediaan untuk menerima pandangan yang berbeda dari orang lain.

3. Cara haruslah sejalan dengan tujuan. Demokrasi pada hakekatnya harus dilakukan secara santun dan beradab yakni melalui proses demokrasi yang dilakukan dengan sukarela. Demokrasi membutuhkan topangan akhlak terpuji (akhlaqul karimah) warga negara. Akhlak demokrasi salah satunya dapat dibuktikan dengan komitmen 
untuk tidak menghalalkan segala cara, seperti dengan kekerasan dan tindakan anarkis demi mencapai tujuan-tujuan politiknya.

4. Norma kejujuran dalam pemufakatan. Suasana masyarakat demokratis dituntut untuk menjalankan permusyawaratan yang jujur dan sehat untuk mencapai kesepakatan yang memberi keuntungan semua pihak. Faktor ketulusan dalam usaha bersama mewujudkan tatanan sosial yang baik untuk warga negara merupakan hal yang sangat penting dalam demokrasi.

5. Kebebasan nurani (freedom conscience), persamaan hak dan kewajiban (egalitarianism). Norma ini harus diintegrasikan dengan sikap percaya pada iktikad baik orang dan kelompok lain (trust attitude). Norma ini juga akan berkembang dengan baik jika ditopang oleh pandang optimis terhadap manusia untuk saling terbuka, saling berbagi kemaslahatan bersama atau untuk melakukan kompromi dengan pihak-pihak yang berbeda.

6. Trial and error (percobaan dan salah). Demokrasi merupakan sebuah proses tanpa henti. Demokrasi membutuhkan percobaan-percobaan dan kesediaan semua pihak untuk menerima kemungkinan ketidaktepatan atau kesalahan dalan praktik berdemokrasi.

Namun demikian, sekalipun demokrasi memperbolehkan kebebasan, demokrasi lebih mengutamakan keberlangsungan ketertiban dan kemaslahatan umum. Dengan kata lain, demokrasi membutuhkan ketegasan negara untuk bertindak tegas terhadap anasiranasir berkedok kebebasan yang mengancam ketertiban umum. Ketegasan juga harus dilakukan pemerintah pusat manakala mendapatkan peraturan daerah (perda) yang dibuat oleh pemerintah di bawahnya bertentangan dengan prinsip universal demokrasi (kemajemukan dan kebaikan bersama) dan semangat UUD 45 serta dasar negara Pancasila. Demi tegaknya prinsip demokrasi, keterlibatan warga negara sangatlah penting untuk mendorong negara bersikap tegas terhadap pandangan dan kebijakan yang bernuansa primordial.

Jika kita mencermati pandangan-pandangan Nurcholish Madjid pro demokrasi, kesannya adalah nilai-nilai etis dan misi yang diemban oleh Islam dan demokrasi nyaris sama, dimana keduanya bermaksud mengantisipasi dan menyelesaikan pertikaian serta mengatur hubungan-hubungan dalam masyarakat agar mereka memperoleh kemajuan dan mendapat hak-haknya secara adil dan utuh. Selain itu, keduanya juga mengandung nilainilai universal, yaitu persamaan, keadilan, kebebasan, dan pluralitas.

Untuk melihat lebih komprehensif pandangan Nurcholish Madjid tentang demokrasi Islam ini, maka dalam tulisan ini penulis akan mengangkat judul Prinsip-Prinsip Islam Tentang Demokrasi (Studi Pemikiran Nurcholish Majid Tahun 1970 sampai tahun 2005). Berangkat dari latar belakang di atas, maka yang menjadi rumusan masalah dalam penelitian ini adalah sebagai berikut; Pertama, bagaimana prinsip-prinsip Islam tentang demokrasi dalam pemikiran Nurcholish Madjid? Kedua, bagaimana implementasi prinsipprinsip Islam tentang demokrasi dalam pemikiran Nurcholish Madjid pada percaturan politik di Indonesia kurun waktu tahun 1970-2005? Dan Ketiga, apa saja faktor pendukung 
dan penghambat dalam menerapkan prinsip-prinsip Islam tentang demokrasi di Indonesia menurut Nurcholish Madjid?.

\section{Kerangka Teori}

Pilihan terhadap suatu teori yang akan digunakan untuk menggarap suatu subjek penelitian tertentu tidak dengan sendirinya dapat digunakan bagi peneliti subjek yang lain. Karena itu peneliti yang bersangkutan perlu memeriksa bahan-bahan secara seksama agar memperoleh kejelasan, untuk memperoleh teori yang digunakan. Sehubungan dengan itu, peneliti yang subjeknya menyangkut prinsip-prinsip demokrasi, akan menggunakan teori demokrasi terutama melalui pendekatan Islam.

Secara umum, ada 3 (tiga) arus besar pendapat para pemikir Islam tentang hubungan Islam dan negara ini, yakni: Pertama, ialah kelompok yang berpendapat bahwa hubungan antara Islam dan negara sangat lekat bahkan Islam mengatur persoalan negara secara eksplisit dan detail. Dengan demikian mendirikan sebuah negara Islam adalah wajib, konstruk negara harus negara Islam. Ajaran Islam harus menjadi dasar konstitusi (Abul A'la al-Maududi, 1967, hlm. 243). Mereka menolak gagasan negara kebangsaan (nation state) karena dinilai bertentangan dengan prinsip ummah. Mereka mengakui prinsip musyawarah tetapi menolak musyawarah sistem demokrasi (Hamid Enayat, 1981, hlm. 35). Jadi menurut pendapat pertama ini adalah, wajib hukumnya memilih imam (khalifah) yang berperan memimpin umat, serta wajib hukumnya menggunakan dasar negara dengan Alquran.

Kedua, mereka menyatakan bahwa tidak ada hubungan antara Islam dengan negara dengan demikian mendirikan negara bukan sebuah kewajiban. 'Ali 'Abd Ar-Ráziq dalam Amad Amir Azis (1999:65) misalnya, tidak setuju dengan konsep negara Islam, bahkan ia menegaskan tidak ada hubungan antara agama dan negara. Menurutnya Allah tidak memberikan jabatan rasul sekaligus sebagai raja kepada nabi Muhammad saw. Buktinya hanya beberapa rasul saja yang menjadi raja seperti nabi Dawud, justru kebanyakannya rasul itu bukan raja, melainkan hanyalah rasul semata (Amad Amir Azis, 1999:65)

Ketiga, di luar kelompok yang pro dan kontra di atas yang pendapatnya dapat dianggap sebagai sebuah sintesa. Kelompok ini mengakui bahwa di dalam Islam memang terdapat ajaran tentang politik dan negara tetapi hanya menyangkut prinsip-prinsipnya saja, tidak menjelaskan secara ekplisit tentang bentuk negara, dasar negara dan ketatanegaran lainnya. Itu semua disesuaikan secara fleksibel dengan keadaan negara masing-masing (Syafii Maarif, 1985, hlm. 16).

Selanjutnya M. Zainuddin (2011, hlm. 5-11) mengatakan bahwa Islam dan demokrasi memang berbeda. Islam berasal dari wahyu, sementara demokrasi berasal dari pergumulan pemikiran manusia. Dalam perspektif Islam elemen-elemen demokrasi meliputi; syura, 'adalah, amanah, mas'uliyyah dan hurriyyah.

Dengan demikian dapat dipahami bahwa jika suatu negara konsisten dengan penegakkan prinsip-prinsip atau elemen demokrasi di atas, maka pemerintahan akan mendapat legitimasi dari rakyat. Oleh karena itu, Nurcholish Madjid (1992, hlm. 35-36) menawarkan 6 norma demokratis yang dibutuhkan oleh tatanan masyarakat, yaitu: 
1. Kesadaran akan pluralisme. Kesadaran atas kemajemukan membutuhkan tanggapan dan sikap positif secara aktif. Pengakuan kenyataan perbedaan harus diwujudkan dalam perilaku menghargai beragam pandangan orang lain. Norma ini dapat mencegah munculnya sikap dan pandangan hegemoni mayoritas dan tirani minoritas. Kenyataan alamiah kemajemukan Indonesia dapat dijadikan modal potensial bagi masa depan demokrasi Indonesia.

2. Musyawarah. Musyawarah menuntut keinsyafan dan kedewasaan warga negara duntuk tulus menerima negosiasi dan kompromi-kompromi sosial dan politik secara damai dan bebas dalam setiap keputusan bersama. Dalam bermusyawarah, setiap orang harus menerima kemungkinan terjadinya "partial functioning of ideals" yaitu belum tentu seluruh pikiran seseorang atau kelompok diterima dan dilaksanakan sepenuhnya. Konsekuensinya adalah kesediaan untuk menerima pandangan yang berbeda dari orang lain.

3. Cara haruslah sejalan dengan tujuan. Demokrasi pada hakekatnya harus dilakukan secara santun dan beradab yakni melalui proses demokrasi yang dilakukan dengan sukarela. Demokrasi membutuhkan topangan akhlak terpuji (akhlaqul karimah) warga negara. Akhlak demokrasi salah satunya dapat dibuktikan dengan komitmen untuk tidak menghalalkan segala cara, seperti dengan kekerasan dan tindakan anarkis demi mencapai tujuan-tujuan politiknya.

4. Norma kejujuran dalam pemufakatan. Suasana masyarakat demokratis dituntut untuk menjalankan permusyawaratan yang jujur dan sehat untuk mencapai kesepakatan yang memberi keuntungan semua pihak. Faktor ketulusan dalam usaha bersama mewujudkan tatanan sosial yang baik untuk warga negara merupakan hal yang sangat penting dalam demokrasi.

5. Kebebasan nurani (freedom conscience), persamaan hak dan kewajiban (egalitarianism). Norma ini harus diintegrasikan dengan sikap percaya pada iktikad baik orang dan kelompok lain (trust attitude). Norma ini juga akan berkembang dengan baik jika ditopang oleh pandang optimis terhadap manusia untuk saling terbuka, saling berbagi kemaslahatan bersama atau untuk melakukan kompromi dengan pihak-pihak yang berbeda. Trial and error (percobaan dan salah). Demokrasi merupakan sebuah proses tanpa henti. Demokrasi membutuhkan percobaan dan kesediaan semua pihak untuk menerima kemungkinan ketidaktepatan atau kesalahan dalan praktik berdemokrasi.

\section{Metodologi Penelitian}

Ada beberapa metode yang penulis gunakan dalam penulisan tesis ini baik yang berkaitan dengan jenis penelitian, metode pendekatan, metode pengumpulan data dan teknik pengumpulan data, sebagaimana dijelaskan berikut ini; jenis penelitian ini adalah penelitian kepustakaan (library research), yaitu mengumpulkan data dan meneliti bukubuku kepustakaan dan karya-karya dalam bentuk lainnya yang berkaitan dengan PrinsipPrinsip Islam tentang Demokrasi menurut Nurcholish Madjid.

Studi yang merupakan penelitian pustaka ini bersifat deskriptif-analitic. Yang dimaksud deskriptif adalah mengambarkan karakteristik dan fenomena yang terdapat 
dalam tokoh Nurcholish Madjid. Dengan kata lain karakteristik dan fenomena yang dikaji dalam penelitian ini adalah pemikiran tokoh Nurcholish Madjid dan implementasi pemikiran prinsip-prinsip Islam tentang demokrasi. Sedangkan analitik adalah analisis dalam pengertian sejarahnya, yakni meneliti sejarah yang melatar belakangi pemikirannya. Dalam hal ini penulis lebih memfokuskan pada karakter dan strategi Nurcholish Madjid dalam membangun pemikiran prinsip-prinsip Islam tentang demokrasi di Indonesia.

Dalam penelitian ini, pendekatan yang digunakan adalah pendekatan sosio-historis. Yang dimaksud pendekatan sosio-historis adalah pendekatan yang menyatakan bahwa setiap produk pemikiran, merupakan hasil interaksi pemikiran dengan lingkungan sosiokultural dan sosio politik yang mengitarinya (Mudzhar, 1998, hlm.105). Berkaitan dengan penelitian ini, adalah kondisi sosial politik dan kultur yang melatar belakangi pemikiran prinsip-prinsip Islam tentang demokrasi. Disamping itu, penulis juga menggunakan pendekatan fenomenologi untuk melihat implementasi pemikiran Nurcholish Madjid.

Pengumpulan data dalam penelitian ini, diperoleh dari literatur-literatur yang berkaitan dengan objek penelitian. Objek penelitian ini adalah Islam dan Demokrasi di Indonesia (Studi Pemikiran Demokrasi Nurcholish Madjid Tahun 1970-2005). Literaturliteratur yang dijadikan sebagai sumber data dalam tesis ini terbagi pada dua bagian yaitu: sumber data primer dan sumber data sekunder. Yang menjadi sumber data primer dalam penelitian ini adalah karya-karya Nurcholish Madjid, Dan data pendukung berupa ensiklopedi, majalah, surat kabar yang berkaitan dengan Nurcholish Madjid ataupun tulisan orang lain tentang demokrasi dan Islam merupakan sumber data sekunder.

Melalui penelusuran dan penelahaan secara mendalam terhadap sumber primer dan sekunder dalam penelitian ini, diharapkan dapat memperoleh mendapatkan data yang akurat dan jelas. Untuk mencapai tujuan tersebut, maka dibutuhkan metode deskriptif dan holistik. Deskriptif adalah menguraikan secara teratur (Anton Baker, 1990, hlm. 65) dari pemikiran Nurcholish Madjid. Dalam penelitian ini, penulis mendeskripsikan dan meredaksikan pemikiran Nurcholish Madjid tentang prinsip-prinsip Islam tentang demokrasi secara sistematis dan mendalam. Sementara holistic adalah metode untuk menggali unsur-unsur yang mempengaruhi pemikiran Nurcholish Madjid, baik lingkungan, latar belakang, agama dan zaman dimana ia hidup. Sebab untuk memahami pemikiran seorang tokoh harus diketahi seluruh proses kehidupannya, sehingga data yang diperoleh dan disajikan lebih jelas dan akurat.

Data-data yang telah dikumpulkan dianalisa secara kualitatif. Kemudian ditarik kesimpulan secara induktif, menurut Anton Baker, (1990, hlm. 67) adalah menarik kesimpulan yang khusus-khusus saja melihat kecenderungan pemikiran Nurcholish Madjid dalam prinsip-prinsip Islam tentang demokrasi.

\section{Diskusi dan Hasil Penelitian}

\section{A. Prinsip-Prinsip Islam Tentang Demokrasi}

Demokrasi memerlukan usaha nyata dari setiap warga dan perangkat pendukungnya yaitu budaya yang kondusif sebagai manifestasi dari suatu kerangka berpikir dan rancangan masyarakat untuk menjadikan demokrasi sebagai pandangan hidup dalam kehidupan bernegara baik oleh rakyat maupun pemerintah. Menurut Nurcholish Madjid (1987, 
hlm.22), demokrasi bukanlah kata benda, tetapi lebih merupakan kata kerja yang mengandung makna sebagai proses dinamis. Karena itu, demokrasi harus diupayakan dan dibiasakan dalam kehidupan sehari-hari. Demokrasi dalam keranga di atas, berarti sebuah proses melaksankan nilai-nilai civility (keadaban) dalam bernegara dan bermasyarakat.

Namun demikian, sekalipun demokrasi memperbolehkan kebebasan, demokrasi lebih mengutamakan keberlangsungan ketertiban dan kemaslahatan umum. Dengan kata lain, demokrasi membutuhkan ketegasan negara untuk bertindak tegas terhadap anasiranasir berkedok kebebasan yang mengancam ketertiban umum. Ketegasan juga harus dilakukan pemerintah pusat manakala mendapatkan peraturan daerah (perda) yang dibuat oleh pemerintah di bawahnya bertentangan dengan prinsip universal demokrasi (kemajemukan dan kebaikan bersama) dan semangat UUD 45 serta dasar negara Pancasila. Demi tegaknya prinsip demokrasi, keterlibatan warga negara sangatlah penting untuk mendorong negara bersikap tegas terhadap pandangan dan kebijakan yang bernuansa primordial.

Oleh karena itu, menurut Nurcholish Madjid (1992, hlm. 37), demokrasi yang dirumuskan "sekali untuk selamanya", sehingga tidak memberikan ruang gerak bagi adanya perkembangan dan perubahan, sesungguhnya bukan demokrasi, melainkan kediktatoran. Pengalaman menunjukkan bahwa begitu orang mencoba merumuskan demokrasi sekali untuk selamanya maka ia berubah menjadi idiologi tertutup. Padahal, demokrasi memerlukan dan memang termasuk idiologi terbuka, yaitu sebuah idiologi yang respek bagi adanya perubahan dan perkembangan melalui eksperimentasi bersama. Justru kekuatan demokrasi terletak dalam sistem bahwa ia mampu, melalui dinamika internnya sendiri, mengadakan kritik ke dalam sekaligus melakukan perbaikan-perbaikan berdasarkan prinsip keterbukaan dan kesempatan untuk bereksperimen.

Menurut Nurcolish Madjid dalam buku Ensiklopedi Nurcholish Madjid (2008, hlm. 499-512) bahwa Islam dan demokrasi memang berbeda. Islam berasal dari wahyu, sementara demokrasi berasal dari pergumulan pemikiran manusia. Dalam perspektif Islam prinsip-prinsip demokrasi meliputi; syura, 'adalah, amanah, mas'uliyyah dan hurriyyah. Untuk lebih jelasnya dapat diuraikan sebagai berikut:

Pertama, Syura merupakan suatu prinsip tentang cara pengambilan keputusan yang secara eksplisit ditegaskan dalam Al-Qur'an yang artinyal

"Dan (bagi) orang-orang yang menerima (mematuhi) seruan Tuhannya dan mendirikan salat, sedang urusan mereka (diputuskan) dengan musyawarah antara mereka; dan mereka menafkahkan sebagian dari rezeki yang Kami berikan kepada mereka" (Qs As-Syura: 38). Kementerian Agama RI 2011. Al-Qur'an (Transliterasi Arab-Latin dan Tejemahnya. Bandung Fokus Media.

Dan firman Allah SWT yang berbunyi:

"Maka disebabkan rahmat dari Allah-lah kamu berlaku lemah-lembut terhadap mereka. Sekiranya kamu bersikap keras lagi berhati kasar, tentulah mereka menjauhkan diri dari sekelilingmu. Karena itu maafkanlah mereka, mohonkanlah 
ampun bagi mereka, dan bermusyawarahlah dengan mereka dalam urusan itu. Kemudian apabila kamu telah membulatkan tekad, maka bertawakallah kepada Allah. Sesungguhnya Allah menyukai orang-orang yang bertawakal kepada-Nya" (Qs Ali Imran: 159). Kementerian Agama RI 2011. Al-Qur'an (Transliterasi ArabLatin dan Tejemahnya. Bandung Fokus Media.

Dalam praktik kehidupan umat Islam lembaga yang paling dikenal sebagai pelaksana syura adalah ahl halli wa-l'aqdi pada zaman khulafaurrasyidin. Lembaga ini lebih menyerupai tim formatur yang bertugas memilih kepala negara atau khalifah. Dengan demikian dapat dipahami bahwa musyawarah sangat diperlukan sebagai bahan pertimbangan dan tanggung jawab bersama dalam setiap mengeluarkan sebuah keputusan. Dengan begitu, maka setiap keputusan yang dikeluarkan oleh pemerintah akan menjadi tanggung jawab bersama. Sikap musyawarah juga merupakan bentuk dari pemberian penghargaan terhadap orang lain karena pendapat yang disampaikan menjadi pertimbangan bersama.

Musyawarah menuntut keinsyafan dan kedewasaan warga negara untuk tulus menerima negosiasi dan kompromi-kompromi sosial dan politik secara damai dan bebas dalam setiap keputusan bersama. Dalam bermusyawarah, setiap orang harus menerima kemungkinan terjadinya "partial functioning of ideals" yaitu belum tentu seluruh pikiran seseorang atau kelompok diterima dan dilaksanakan sepenuhnya. Konsekuensinya adalah kesediaan untuk menerima pandangan yang berbeda dari orang lain.

Kedua Al-'adalah, artinya dalam menegakkan hukum termasuk rekrutmen dalam berbagai jabatan pemerintahan harus dilakukan secara adil dan bijaksana. Artinya pentinnya penegakkan keadilan dalam sebuah pemerintahan ini ditegaskan oleh Allah SWT dalam beberapa ayat-Nya, antara lain dalam surat yang berbunyi:

"Sesungguhnya Allah menyuruh (kamu) berlaku adil dan berbuat kebajikan, memberi kepada kaum kerabat, dan Allah melarang dari perbuatan keji, kemungkaran dan permusuhan. Dia memberi pengajaran kepadamu agar kamu dapat mengambil pelajaran" (Qs an-Nahl: 90). Kementerian Agama RI 2011. AlQur'an (Transliterasi Arab-Latin dan Tejemahnya. Bandung Fokus Media.

Firman Allah SWT dalam al-qur'an yang berbunyi:

"Mereka berdoa: Ya Tuhan kami, janganlah Engkau jadikan hati kami condong kepada kesesatan sesudah Engkau beri petunjuk kepada kami, dan karuniakanlah kepada kami rahmat dari sisi Engkau; karena sesungguhnya Engkau-lah Maha Pemberi (karunia)" (Qs Al-Imran: 8). Kementerian Agama RI 2011. Al-Qur'an (Transliterasi Arab-Latin dan Tejemahnya. Bandung Fokus Media.

Betapa prinsipnya keadilan dalam sebuah negara sangat diperlukan, sehingga ada ungkapan yang ekstrim berbunyi "negara yang berkeadilan akan lestari kendati ia negara kafir, sebaliknya negara yang zalim akan hancur meski ia negara Islam. 
Ketiga al-Musawah adalah kesejajaran, artinya tidak ada pihak yang merasa lebih tinggi dari yang lain sehingga dapat memaksakan kehendaknya. Penguasa tidak bisa memaksakan kehendaknya terhadap rakyat, berlaku otoriter dan eksploitatif. Kesejajaran ini penting dalam sebuah pemerintahan demi menghindari dari hegemoni penguasa atas rakyat.

Keempat al-Amanah adalah sikap pemenuhan kepercayaan yang diberikan seseorang kepada orang lain. Oleh sebab itu, kepercayaan atau amanah tersebut harus dijaga dengan baik. Dalam konteks kenegaraan, pemimpin atau pemerintah yang diberikan kepercayaan oleh rakyat harus mampu melaksanakan kepercayaan tersebut dengan penuh rasa tanggung jawab. Persoalan amanah ini terkait dengan sikap adil seperti ditegaskan Allah SWT yang berbunyi:

"Sesungguhnya Allah menyuruh kamu menyampaikan amanat kepada yang berhak menerimanya, dan (menyuruh kamu) apabila menetapkan hukum di antara manusia supaya kamu menetapkan dengan adil. Sesungguhnya Allah memberi pengajaran yang sebaik-baiknya kepadamu. Sesungguhnya Allah adalah Maha Mendengar lagi Maha Melihat" (Qs An-Nisa: 58). Kementerian Agama RI 2011. Al-Qur'an (Transliterasi Arab-Latin dan Tejemahnya. Bandung Fokus Media.

Karena jabatan pemerintahan adalah amanah, maka jabatan tersebut tidak bisa diminta dan orang yang menerima jabatan seharusnya merasa prihatin bukan malah bersyukur atas jabatan tersebut.

Kelima al-Mas'uliyyah adalah tanggung jawab. Sebagaimana diketahui bahwa kekuasaan dan jabatan itu adalah amanah yang harus diwaspadai bukan nikmat yang harus disyukuri, maka rasa tanggung jawab bagi seorang pemimpin atau penguasa harus dipenuhi. Kekuasaan sebagai amanah ini memiliki dua pengertian, yaitu amanah yang harus dipertanggungjawabkan di depan rakyat dan juga amanah yang harus dipertanggungjawabkan di depan Tuhan. Dengan demikian pemimpin atau penguasa tidak ditempatkan pada posisi sebagai sayyid al-ummah (penguasa umat) melainkan sebagai khadim al-ummah (pelayan umat).

Keenam al-Hurriyyah adalah kebebasan, artinya bahwa setiap orang, setiap warga masyarakat diberi hak dan kebebasan untuk mengeksperisikan pendapatnya. Sepanjang hal itu dilakukan dengan cara yang bijak dan memperhatikan al-akhlaq al-karimah dan dalam rangka al-amr bi-'l-ma'ruf wa an-nahy 'an al-'mungkar, maka tidak ada alasan bagi penguasa untuk mencegahnya.

Kebebasan nurani (freedom conscience), persamaan hak dan kewajiban (egalitarianism). Norma ini harus diintegrasikan dengan sikap percaya pada iktikad baik orang dan kelompok lain (trust attitude). Norma ini juga akan berkembang dengan baik jika ditopang oleh pandang optimis terhadap manusia untuk saling terbuka, saling berbagi kemaslahatan bersama atau untuk melakukan kompromi dengan pihak-pihak yang berbeda.

Untuk menerapkan prinsip-prinsip demokrasi tersebut, menurut Nurcholish Madjid (1992, hlm. 35-36) ada beberapa norma demokratis yang harus dilakukan oleh berbagai pihak, yaitu: pertama, kesadaran akan pluralisme. Kesadaran atas kemajemukan 
membutuhkan tanggapan dan sikap positif secara aktif. Pengakuan kenyataan perbedaan harus diwujudkan dalam perilaku menghargai beragam pandangan orang lain. Norma ini dapat mencegah munculnya sikap dan pandangan hegemoni mayoritas dan tirani minoritas. Kenyataan alamiah kemajemukan Indonesia dapat dijadikan modal potensial bagi masa depan demokrasi Indonesia.

Kedua, harus mengedepankan nilai-nilai akhlakul karimah. Demokrasi pada hakekatnya harus dilakukan secara santun dan beradab yakni melalui proses demokrasi yang dilakukan dengan sukarela. Demokrasi membutuhkan topangan akhlak terpuji (akhlaqul karimah) warga negara. Akhlak demokrasi salah satunya dapat dibuktikan dengan komitmen untuk tidak menghalalkan segala cara, seperti dengan kekerasan dan tindakan anarkis demi mencapai tujuan-tujuan politiknya. Ketiga, norma kejujuran dalam pemufakatan. Suasana masyarakat demokratis dituntut untuk menjalankan permusyawaratan yang jujur dan sehat untuk mencapai kesepakatan yang memberi keuntungan semua pihak. Faktor ketulusan dalam usaha bersama mewujudkan tatanan sosial yang baik untuk warga negara merupakan hal yang sangat penting dalam demokrasi.

Keempat, kebebasan nurani (freedom conscience), persamaan hak dan kewajiban (egalitarianism). Norma ini harus diintegrasikan dengan sikap percaya pada iktikad baik orang dan kelompok lain (trust attitude). Norma ini juga akan berkembang dengan baik jika ditopang oleh pandang optimis terhadap manusia untuk saling terbuka, saling berbagi kemaslahatan bersama atau untuk melakukan kompromi dengan pihak-pihak yang berbeda. Kelima, Trial and error (percobaan dan salah). Demokrasi merupakan sebuah proses tanpa henti. Demokrasi membutuhkan percobaan-percobaan dan kesediaan semua pihak untuk menerima kemungkinan ketidaktepatan atau kesalahan dalan praktik berdemokrasi.

Senada dengan apa yang dikemukakan oleh Nurcholish Madjid tersebut Hendra Nurtjahjo (2006: hlm. 77), menyatakan bahwa secara isensial prinsip demokrasi diklasifikasikan kepada tiga nilai utama yang mendasari tumbuhnya teori demokrasi, baik yang bersifat subtansial dan instrumental. Adapun prinsip-prinsip tersebut yaitu: Pertama, prinsip kebebasan merupakan kebebasan manusia terhadap segala bentuk kekangan dan kekuasaan sewenang-wenang baik dibidang agama maupun dibidang pemikiran politik. Mengenai kebebasan ini Magnis Suseno (2006: hlm. 77) mengemukakan bahwa kebebasan adalah tanda dan ungkapan martabat manusia. Karena kebebasannya manusia adalah makhluk yang otonom, yang menentukan diri sendiri, yang dapat mengambil sikapnya sendiri. Setiap pemaksaan dirasakan sebagai sesuatu yang tidak hanya buruk dan menyakitkan, melainkan juga menghina. Dan memang demikian; memaksakan sesuatu kepada orang lain berarti mengabaikan martabatnya sebagai manusia yang sanggup untuk mengambil sikapnya sendiri. Maka kita merasa paling terhina kalau sesuatu dipaksakan kepada kita dengan ancaman atau bujukan. Kalau diminta, artinya kalau kebebasan kita dihormati, kita sering bersedia untuk memberikan dengan hati yang lapang, tetapi kalau kita dipaksa, kita merasa terhina dan tidak mau. Kebebasan adalah mahkota martabat kita sebagai manusia".

Lebih jauh Magnis (2006: hlm. 78) menjelaskan bahwa akar kebebasan adalah kemampuan manusia untuk menentukan dirinya sendiri atau disebut sebagai "kebebasan eksistensial". Kebebasan tersebut berakar dalam kebebasan rohani manusia, yaitu dalam 
penguasaan manusia terhadap batinnya, terhadap pikiran dan kehendaknya.. Dengan demikian kebebasan manusia secara hakiki terbatas pula oleh kenyataan bahwa manusia hidup bersama dengan manusia-manusia lain (kehidupan sosialnya).

Prinsip kebebasan dalam konteks politik dipahami sebagai kemampuan untuk memilih secara bebas. Hak untuk menentukan pilihan secara bebas dan eliminasi terhadap pemaksaan kehendak dari banyak kemungkinan pilihan yang ada menjadi isensial dalam konteks politik yang demokratis. Oleh karenanya, kedudukan kebebasan individu menjadi signifikan terhadap kondisi politik yang dianggap demokratis, baik kebebasan yang sama dalam hukum, sipil dan politik yang menjadi ciri dan prinsip dari teori demokrasi modern.

Kedua, prinsip kesamaan yang merupakan ciri eksistensial dari demokrasi yang dipahami sebagai memperlakukan semua orang sama dan sederajat. Secara garis besar demokrasi menghendaki persamaan atau kesamaan hak-hak dalam menjalankan peran politik dalam konteks negara. Kesamaan hak-hak politik pada implementasinya secara prosedural dimanefestasikan dalam prinsip "one man one vote" dengan tidak membedakan kualitas individunya apakah seorang yang kaya atau miskin, penjahat ataupun orang yang shaleh. Kedua-duanya tetap sama hanya memiliki satu suara dalam konteks pemilihan atau pelaksanaan hak-hak politik.

Selanjutnya, Hendra Nurtjahjo (2006: hlm. 77), mengatakan bahwa kebebasan dalam pandangan komplementaris secara prinsip selalu mengasumsikan adanya persamaan. Sebaliknya, kesamaan juga mengasumsikan adanya kebebasan. Dalam hal ini terdapat kondisi dikotomis atau simbosis mutualisme yang erat antara keduanya. Artinya dalam tataran implementatif sangat sulit jika suatu kehidupan masyarakat yang dipenuhi dengan kebebasan, tetapi tidak mengakui adanya persamaan hak dan kewajiban kemanusian di dalamnya. Sebaliknya, jika suatu kehidupan masyarakat yang menghargai persamaan sosial, tetapi tidak memiliki kebabasan dalam mengungkapkan potensi-potensi kemanusiaan secara individu maupun kolektif. Oleh karenanya, kedua prinsip tersebut dapat dikomplementer atau saling melengakapi satu sama lain.

Ketiga, prinsip kedaulatan rakyat yang merupakan fenomena lanjutan setelah kebebasan dan kesamaan. Kedaulatan rakyat adalah konsekuensi logis dari adanya kebebasan dan kesamaan manusia yang kemudian menghendaki adanya hirarki penguasaan yang di dasarkan atas persetujuan lebih dahulu dari orang-orang yang sama hak tersebut dapat diperintah. Rakyat sendiri yang berhak menentukan siapa dan bagaimana mereka harus diperintah dalam struktur kehidupan bernegara. Rakyat juga berhak sama menarik mandat dari orang-orang yang tidak dapat mewujudkan dan menjalankan aspirasi mereka.

Kelanjutan dari prinsip kedaulatan rakyat kemudian diterminasi ke dalam bentuk pengambilan keputusan secara demokratis sebagai konklusi kehendak dan persetujuan rakyat. Dalam hal ini, konsekwensinya hanya bisa ditunjukkan melalui cara kesepakatan atau suara mayoritas akan menjadi pegangan utama. Jadi, demokrasi dalam level pelembagaan pembuatan keputusan menuntut persetujuan bersama oleh mayoritas partisipan yang ditentukan secara bebas dan sebagai manifestasi dari kesamaan hak dalam menentukan kehendak.

Dari ketiga prinsip tersebut, demokrasi kemudian berkembang tidak hanya sebatas ide, melainkan juga banyak varian praktis guna mewujudkan nilai ideal yang universal 
dengan kebutuhan lokal dari suatu masyarakat atau negara tertentu yang pada akhirnya menjadi basis implementasi dari hak-hak warga negara dan dapat dipahami juga terjadi pergeseran dari dunia teoritis dan praktis.

\section{B. Implementasi Prinsip-Prinsip Islam Tentang Demokrasi dalam Pemikiran Nurcholish Madjid pada Percaturan Politik di Indonesia}

Penerapan prinsip-prinsip Islam tentang demokrasi dalam percaturan politik di Indonesia sejak masa ordebaru sampai awal masa reformasi, masih belum dapat dilakukan, hal ini disebabkan oleh beberapa hal berikut ini:

Pertama kokohnya cengkeraman kekuasaan rezim yang memerintah. Dalam Pintupintu Mепијu Tuhan, Nurcholish mengkritisi pelaksanaan demokrasi di Indonesia yang mana seringkali orang-orang yang mengembar-gemborkan demokrasi ternyata kadang bertindak menipu rakyat dan menjadi diktator. Nurcholish menulis (1995, hlm. 256): "Setelah hampir setengah abad merdeka, bicara tentang demokrasi di negeri kita ibarat mengunjungi sebuah rumah antik,..., demokrasi antik di Indonesia bukan ide dasarnya, melainkan kontroversinya. Dalam sejarah sekitar proklamasi, kita dapati masalah demokrasi telah menjadi bahan perdebatan sengit antara para pendiri republik. Kita kenal jargon-jargon mereka: "dewan," "perwakilan," rakyat," "majelis," "musyawarah," "mufakat," dan seterusnya. Juga ada pinjaman yang lebih kontemporer: "delegation of authority, "rule of law," "majority rule and minority right", dan entah apa lagi. Kita kenal semuanya. Tapi rasanya tidak mungkin kita mengakui benar-benar mengerti maksudnya, apa lagi menggambarkan dengan tepat bagaimana masing-masing yang mengklaim demokrasi itu bertingkah laku."

Nurcholish (1995, hlm. 257) mengambil contoh bahwa Bung Karno yang dengan kemampuan retoriknya membela demokrasi tetapi ia jatuh dengan tuduhan sebagai diktator karena membiarkan usaha kultus individu terhadap dirinya. Bagi Nurcholish (1999, hlm. 5) demokrasi memang suatu sistem politis yang mesti dikembangkan. Stabilitas politik hanya dapat dicapai dengan penyelenggaran kekuasaan yang demokratis. Ciri kekuasaan demokratis yang stabil adalah ia memiliki kemungkinan tinggi untuk tetap demokratis dan mempunyai tingkat yang rendah untuk mengalami gangguan kekerasan sosial, baik yang terbuka maupun yang tersembunyi.

Kedua, adanya konsensus politik dan keseragaman sosial. Nurcholish (1999, hlm. 6-7) tidak menolak bahwa demokrasi memang cukup sulit dilaksanakan dalam masyarakat yang majemuk. Hal itu disebabkan konsensus politik dan keseragaman sosial adalah faktor penting bagi kestabilan demokrasi. Setiap bentuk pengaturan politik yang tangguh dan absah, lebih-lebih lagi yang demokratis, memerlukan ikatan bersama yang antara lain berbentuk kesetiaan dasar, suatu komitmen yang lebih menggerakkan perasaan, yang lebih terasa hangat dalam lubuk jiwa daripada seperangkat prosedur.

Menurut Nurcholish (1999, hlm. 12), konsensus dalam politik memang dapat juga beresiko sebab demokrasi menjadi tidak sehat dengan banyaknya konsensus. Maka demokrasi yang stabil memerlukan perimbangan yang wajar antara konsensus dan perbedaan, atau malah konflik. Hanya saja, konflik mesti bertujuan sebagai proses belajar bagi persoalan yang sulit diatasi. 
Dalam menyeimbangkan konsensus dan konflik, dibutuhkan pemimpin yang cakap. Dalam hal ini, kehendak politik pemimpin turut menentukan. Pemimpin tidak hanya memberi teladan tetapi juga belajar dari rakyat. Memang dapat terjadi bahwa pemimpin bertindak demi "menjilat" orang banyak. Akan tetapi hal itu mesti dihindari. Selain itu itikad baik pemimpin mesti diwujudkan dalam tindakan nyata. Dalam merumuskan tindakan nyata itu, pemimpin mesti mengakomodasi kebebasan rakyat untuk menyatakan pendapat dalam dialog demi tercapai komitmen dan tanggung jawab bersama (Nurcholish Madjid, 1999, hlm. 14-15).

Padahal menurut Nurcholish Madjid (1999, hlm. 52-54) bangsa Indonesia yang mayoritas menganut Islam, telah memiliki modal dasar yang kuat untuk menerapkan prinsip-prinsip Islam tentang demokrasi tersebut. Modal dasar ini adalah bahwa Islam dapat menjamin keberlangsungannya. Hal itu tak terlepas ciri inklusif Islam, yaitu bahwa Islam menghendaki suatu sistem yang menguntungkan semua orang. Dalam perjalanan sejarahnya, Islam telah mempraktekkan nilai-nilai semacam prinsip toleransi agama dan kebebasan beribadat, penghargaan kepada warisan budaya kelompok lain, penghargaan kepada hak-hak sah pribadi, dan sikap yang positif terhadap ilmu pengetahuan.

Selanjutnya menurut Nurcholish (1999, hlm. 56-57), adanya Pancasila dan UUD 1945 telah diterima oleh umat Muslim Indonesia. Sejauh ini, kedua pilar itu telah mampu menjamin kebaikan konstitusional bagi keseluruhan bangsa. Pada hakekatnya, Pancasila dan UUD 1945 diterima masyarakat Muslim karena dua pertimbangan:...."Pertama, nilainilainya dibenarkan oleh ajaran agama Islam. Kedua, fungsinya sebagai poin kesepakatan antar berbagai golongan untuk mewujudkan kesatuan politik bersama."

Dalam menghadapi kenyataan Indonesia, Nurcholish (1999, hlm. 69) melihat demokrasi sebagai sistem yang cocok. "Tentu saja kita memilih demokrasi sebagai ideologi politik. Dan kita memilih demokrasi sebagai ideologi tidak hanya karena pertimbangan prinsipil yaitu karena nilai demokrasi itu menurut kita dibenarkan dan didukung oleh semangat Islam tetapi juga karena fungsinya sebagai aturan permainan politik yang terbuka."

Kemudian, menurut Nurcholish (1999, hlm. 70), demokrasi memungkinkan adanya aturan permainan politik yang terbuka yang kemudian memungkinkan sistem politik Indonesia dapat menjalankan pengawasan terbuka terhadap pelaksanaan pemerintahan dan penggunaan kekuasaan yang menyimpang dari kepentingan rakyat. Pengawasan itu penting dilaksanakan karena dalam usaha mewujudnyatakan garis-garis besar konstitusi, akan terjadi tarik-menarik kepentingan.

Untuk itu, demokrasi harus tetap berkembang dalam proses keseharian hidup masyarakat Indonesia. Antara keadaan masyarakat Indonesia dan cita-cita demokratis memang terdapat gap. Oleh karena itu, proses demokratisasi harus selalu didorong. Dalam usaha itu, suatu masyarakat disebut demokratis jika nilai-nilai demokratis dikembangkan. Nilai-nilai itu misalnya pengakuan hak-hak asasi manusia, kebebasan menyatakan pendapat, kebebasan berserikat, tertib dan keadilan hukum, dan tersedianya kesempatan yang merata.

Selain itu, Nurcholish (1999, hlm. 71) menyatakan bahwa demokrasi merupakan kategori yang dinamis, sehingga demokrasi menjadi identik dengan proses demokratisasi. 
Hal ini menjadikan bahwa negara paling demokratis pun dapat dicap tidak demokratis jika mengalami kemandekan dalam memperjuangkan nilai demokrasi. Bagi konteks Indonesia, pencapaian kualitas demokrasi yang lebih baik hanya tercapai sejauh tampak dalam usahausaha pengkonkretan penerapan prinsip-prinsip demokrasi.

Dalam ungkapan yang lain, Nurcholish (1999, hlm. 93) juga memandang bahwa demokrasi Indonesia memuat beberapa hal penting. Pertama, demokrasi Indonesia tidak mungkin tanpa adanya Pancasila dan UUD 1945 sebagai prinsip-prinsip yang dipraanggapkan sebagai dengan sendirinya benar. Kedua, demokrasi tidak mungkin dijalankan tanpa adanya stabilitas keamanan negara. Dalam pendapat kedua ini, Nurcholish bermaksud menyinggung peran aparat keamanan dalam demokrasi Indonesia.

Berkaitan dengan Pancasila, Nurcholish (1999, hlm. 103) menyebut bahwa Pancasila adalah modal untuk mewujudkan demokrasi Indonesia. Pancasila memberi dasar dan prasyarat asasi bagi demokrasi dan tatanan politik Indonesia. Pancasila menyumbang beberapa hal penting. Pertama, adanya orientasi hidup transendental. Kedua, ikatan batin pada nilai-nilai kemanusiaan. Ketiga, kesadaran akan tanggung jawab bersama. Keempat, pandangan yang mendahulukan kepentingan masyarakat daripada kepentingan pribadi. Kelima, di tengah antara yang empat itu, prasarana dan wadah persatuan dan kesatuan bangsa.

Dengan menerima demokrasi sebagai sistem politis, adalah suatu tuntutan bagi masyarakat Indonesia menjadikan demokrasi sebagai cara hidup (way of life). Tuntutan itu meskipun telah tampak dalam kehidupan berbangsa, tetapi tetap harus selalu diperjuangkan. Nurcholish (1995, hlm. 45) mengidentifikasi beberapa hal bagi perwujudan konkret demokrasi Indonesia. Pertama, pentingnya kesadaran kemajemukan. Hal ini tidak berarti menerima kemajemukan bangsa Indonesia begitu saja tetapi menerimanya secara aktif. Dalam cara hidup demokratis, setiap individu mengarahkan dirinya kepada persatuan dan kesatuan yang diperoleh secara kreatif dari dinamika dan kemajemukan masyarakat. Setiap orang memelihara dengan teguh keanekaragaman.

Kedua, musyawarah. Menurut Nurcholish (1995, hlm. 47), musyawarah menuntut adanya kedewasaan untuk dengan tulus menerima kemungkinan kompromi atau bahkan kalah suara. Semangat musyawarah menuntut agar setiap orang menerima kemungkinan terjadinya penerimaan dan penolakan pendapat. Dalam hal ini, dituntut kedewasaan untuk mengemukakan pendapat, untuk mendengarkan pendapat orang lain, dan kemungkinan untuk menerima pendapat yang lebih baik. Kebiasaan untuk mengkritik secara sehat perlu dikembangkan.

Ketiga, cara-cara yang sejalan dengan tujuan. Menurut Nurcholish (1995, hlm. 48) adanya ungkapan "tujuan menghalalkan cara" adalah suatu kritik terhadap orang-orang yang tidak memperdulikan pertimbangan moral dalam tindakannya. Cara hidup demokratis mewajibkan suatu cara yang sejalan dengan tujuan. Dalam argumen ini, Nurcholish bermaksud menyinggung pentingnya akhlak.

Keempat, permufakatan yang jujur dan sehat. Menurut Nurcholish, masyarakat demokratis menuntut kemampuan untuk menjalankan seni permusyawaratan yang jujur dan sehat. Oleh karena itu, setiap masyarakat Indonesia dituntut untuk tulus, berani terbuka terhadap orang lain. Kelima, pemenuhan kebutuhan pokok, sandang, pangan, papan, bagi 
segenap rakyat Indonesia. Keenam, kerjasama antar warga masyarakat dengan dasar sikap saling mempercayai. Dalam hal ini, pengakuan akan kebebasan nurani, persamaan hak dan kewajiban, dan tanpa perasaan curiga adalah nilai yang harus diperjuangkan.

Kelima, pentingnya pendidikan demokrasi. Nurcholish memandang bahwa hal ini perlu diperjuangkan. Hal ini tidak bermaksud menganjurkan proses indoktrinasi konsep demokrasi tetapi bahwa nilai-nilai universal demokrasi mesti disatukan dalam sistem pendidikan. Hal ini dikarenakan bahwa demokrasi itu bukan sistem yang bekerja dengan sendirinya tetapi harus dibiasakan dan diperjuangkan.

Selanjutnya menurut Nurcholish (1995, hlm. 48), demokrasi memang menampakkan salah satu sisinya dalam pemilihan umum yang bebas dan pemberian suara secara rahasia. Akan tetapi, demokrasi tidak berhenti disitu. Demokrasi mesti "tinggal" di tengah masyarakat. Masyarakat itulah yang disebut masyarakat madani (civil society). Dalam masyarakat madani, terdapat berbagai perserikatan, persatuan, federasi yang bergabung untuk menjadi perisai antara negara dan warganya.

Dalam kenyataannya, civil society lebih dari sekadar campuran berbagai bentuk asosiasi. Civil society membutuhkan kualitas civility, yang mana tanpanya lingkungan hidup sosial akan hanya terdiri dari faksi-faksi, dan serikat-serikat rahasia yang saling menyerang. civility mengandung makna toleransi, kesediaan menerima berbagai pribadi, untuk menerima perbedaan, juga kesediaan untuk menerima bahwa sesuatu persoalan dapat saja tak terpecahkan. Menurut Nurcholish (1995, hlm. 50), meskipun masyarakat madani dapat berfungsi sebagai oposisi terhadap pemerintah, pemerintah mesti tetap menjalankan fungsinya sebagai pemegang hukum, pembuat aturan, dan penertib masyarakat madani karena civil society bukanlah pemerintah.

Bagi kalangan neo-modernis Islam di Indonesia seperti Nurcholish Madjid (1992, hlm. 35-36) bahwa demokrasi dan agama sesungguhnya dapat dipertemukan. Demokrasi dipandang sebagai aturan politik yang layak, sementara agama diposisikan sebagai wasit moral dalam penerapan demokrasi. Nurcholish Madjid mengemukakan demokrasi dalam masyarakat Islam yang dianggapnya bisa dikompromikan. Pertama, secara umum dalam masyarakat, agama menjadi simbol identitas, sehingga mau tidak mau jalan demokrasi leberal harus melewati pintu politik agama. Dengan demikian, proses demokratisasi tidak bisa secara artifisial dilepaskan dari diskursus seputar aturan normatif agama dalam pemerintahan.

Kedua, dalam demokrasi leberal membutuhkan sekularisme, karenanya tradisi agama tidak dilahirkan inheren sekuler dan memiliki konsepsi khusus tentang demokrasi politik. Dengan demikian, sekularisme muslim memungkinkan dan sangat dibutuhkan untuk meningkatkan demokrasi liberal di dalam masyarakat muslim. Ketiga, ada hubungan yang intim antara reformasi agama dan perkembangan politik, yaitu yang lebih awal biasanya mendahului yang terakhir, dimana proses tersebut secara mendalam saling terhubung. Demokratisasi tidak mengharuskan privitalisasi agama, tetapi membutuhkan reinterpretasi ide-ide keagamaan yang lebih kondusif untuk demokrasi liberal. Dengan reinterpretasi, ini kelompok agama akan memainkan peran penting dalam pertumbuhan dan konsolidasi demokrasi. 
Lebih jauh Nurcholish Madjid (1992, hlm. 38-40) mengemukakan bahwa pertama, Islam di Indonesia mempunyai keterlibatan dalam kegiatan kewarganegaraan dan jaringan keterlibatan dalam perkumpulan sesama muslim, justru memperkuat keterlibatan orang dengan kegiatan yang bersifat sekuler. Kedua, keterlibatan umat Islam di Indonesia dalam kegiatan keagamaan dan sekuler membuat umat Islam di Indonesia dalam kegiatan keagamaan dan sekuler membuat umat Islam toleran terhadap kelompok lain. Ketiga, umat Islam di Indonesia justru memberikan kontribusi yang positif bagi munculnya partisipasi demokrasi. Keempat, umat Islam yang shaleh di Indonesia tidak mengancam konsolidasi demokrasi. Kelima, ada sejumlah nilai dalam Islam yang diyakini mendukung demokrasi, yakni melalui ijtihat (penalaran rasional), ijma (konsensus), ikhtilaf perbedaan pendapat, dan syura (konsultasi).

Keenam, muslim di Indonesia sangat mendukung negara bangsa. Konsepsi tentang ummah tidak otomatis bertentangan dengan gagasan negara bangsa. Unsur-unsur ibadah dalam Islam justru makin memperkuat keterlibatan umat Islam di Indonesia dengan berbagai masalah masyarakat tak hanya terkait dalam urusan agama. Ketujuh, partisipasi politik bagi masyarakat muslim terkait dengan karakteristik obyek dari partisipasi tersebut, apakah terkait kerangka norma Islam atau tidak. Karena, itu bila obyek partisipasi tidak ada kaitannya dengan Islam, dan partisipasi itu menjadi kecil kemungkinan. Ke delapan, tak ada kaitan antara keimanan seseorang muslim dengan ketetarikan dengan politik dan kepercayaan terhadap institusi politik. Seorang muslim yang toleran justru cenderung tidak aktif dalam politik dan bukan merupakan ancaman bagi demokrasi.

Terlepas dari pandangan di atas, Nurcholish Madjid (1995, hlm. 36), mengemukakan masih ada sebagian kelompok kecil umat Islam yang kurang apresiatif terhadap demokrasi. Setidaknya terdapat dua faktor yang menyebabkan demokrasi belum diterima oleh sebagian umat Islam. Pertama, munculnya sikap anti dan ketakutan terhadap Barat. Yang kemudian sikap ini melahirkan phobia dan apriori terhadap semua yang dianggap sebagai produk Barat. Sikap ini muncul karena adanya " trauma historis" dimana imprealisme Barat dianggap sebagai pihak yang harus bertanggung jawab atas kemunduran dan penindasan dunia Islam.

Kedua, negara-negara yang berpenduduk mayoritas Islam secara umum belum bisa dianggap sebagai negara demokrasi, bahkan sebagian masih mempertahankan sistem monarki tradisional, dimana kekuasaan masih berpusat pada suatu kelompok orang. Realitas ini tentu saja kurang menguntungkan bagi sosialisasi gagasan demokrasi di negara Islam, karena bisa melahirkan benturan-benturan dengan kekuasaan. Implikasinya prinsipprinsip dasar Islam yang mempunyai relevansi dengan nilai-nilai dasar demokratis kurang muncul kepermukaan, sementara yang muncul justru kecenderungan untuk menjadikan Islam sebagai legitimasi politik.

Oleh karenanya, Nurcholish Madjid (1999, hlm. 67) mengemukakan demokrasi sebagai idiologi, tidak hanya karena pertimbangan-pertembangan prinsipil, karena nilainilai demokrasi dinenarkan dan di dukung oleh semangat ajaran Islam yang berlandaskan Teks Al-Qur'an dan juga fungsinya sebagai aturan permainan politik yang terbuka. Ringkasnya, bagi Nurcholish Madjid terdapat banyak titik temu antara agama dan demokrasi khususnya bila dikaitkan dengan tujuan kedua-duanya, yaitu cita-cita untuk 
kebaikan semua. Sehingga tidak heran jika penerimaan umat Islam terhadap demokrasi bersifat sangat alami.

Secara umum, demokrasi selalu menjadi perhatian kemanusian di seluruh dunia karena demokrasi menawarkan pilar peradaban dan nilai-nilai yang bisa dikatakan selaras dengan ajaran atau idiologi agama. Pertama, golongan yang mengatakan bahwa Islam tidak kompatibel dengan demokrasi. Dalam hal ini, pandangan pemikiran yang mewakilinya Ali Kedourie. Menurut Ali Kedourie (1998, hlm 77), peradaban Islam sangat unik sehingga kaum muslimin banga dengan peradabannya tersebut dalam sejarah Islam. Peradaban ini, bagi Kedourie menghambat kaum muslimin untuk mempelajari dan menghargai, kemajuan politik dan sosial yang dicapai oleh peradaban lain, terutama sistem demokrasi.

Sikap yang sama ditujukan oleh Bernard dalam Saiful Mujani (2007, hlm. 13) bahwa Islam adalah sebuah ajaran sempurna dan komprehensif yang mengatur seluruh aspek kehidupan seseorang muslim. Termasuk di dalamnya adalah masalah politik, yang tidak mengenal pemisahan antara aturan agama atau aturan negara. Oleh karena itu, sekularisme sebagai faktor penting dalam demokrasi moderen merupakan sebuah aliansi dari masyarakat muslim. Pandangan akan kesempurnaan ajaran tersebut menutup mata kaum muslimin untuk belajar demokrasi yang notabene dari peradaban lain atau berasal dari barat.

Pandangan yang sama juga di paparkan oleh Huntington dalam Saiful Mujani (2007, hlm. 13), menurutnya masyarakat Islam tidak mempunyai akar-akar budaya demokratis bahkan keduanya bersifat antagonistik dan kontradiktif. Salah satu kegagalan demokrasi di negara-negara muslim antara lain disebabkan oleh watak dan budaya masyarakat Islam yang tidak ramah atas konsep-konsep liberalisme Barat. Sebab pertentangan Islam dan demokrasi bukan saja muncullnya fundamentalisme Islam, tapi karena Islam itu sendiri.

Jika ditelaah lebih jauh dari pemikiran Kedourie, Lewis, dan Huntington bahwa Islam hubungannya dengan politik adalah sebagai berikut: pertama, Islam merupakan pandangan hidup yang total berlandaskan syari'at dan mengatur seluruh aspek kehidupan individu dan masyarakat Islam, oleh karena itu tidak ada perbedaan agama dengan politik. Kedua, Islam sebagai pandangan hidup bukan hanya gejala pikiran melainkan arus utama. Ketiga, Islam bersikap antagonis terhadap demokrasi di masyarakat muslim tidak akan tumbuh. Hal ini nampak pada ketidak puasan kaum muslimin pada rezim yang demokratis bukan karena kinerja demokrasi yang buruk, namun adanya kontradiksi antara demokrasi dan budaya politik Islam.

\section{Faktor Pendukung dan Penghambat dalam Menerapkan Prinsip-Prinsip Islam Tentang Demokrasi di Indonesia}

Dalam membuka file sejarah penerapan prinsip-prinsip demokrasi Islam di Indonesia, tentu saja mengingatkan kita pada kondisi peta Islam di Indonesia yang saat itu dan sesudahnya, yang telah banyak memberikan kontribusi atas terwujudnya transformasi sosial dan berlakunya sebuah proses demokratisasi yang sedang melangkah sedikit demi sedikit di Indonesia. Melihat hal itu, maka tak terbantahkan, bahwa Islam di Indonesia (Ma'arif, 1999, hlm. 68), sejatinya juga telah memberikan kontribusi atas hadirnya proses iklim 
demokratisasi pasca jatuhnya rezim otoriter Soeharto (Mulkhan,1992, hlm. 15-16). Kontribusi tersebut bisa dicermati dari dua sisi pandangan. Pertama, bisa terlihat dari sisi cita-cita normatif. Maksudnya adalah, bahwa Islam sebagai sebuah agama, sesungguhnya telah meletakkan beberapa dasar prinsip demokrasi dalam beberapa ajarannya seperti; shura (permusyawaratan), al- 'adalah (keadilan), ijma' (konsensus), ijtihâd (kemerdekaan berpikir), tasamuh (tolerensi), al-hurrîyah (kebebasan), al-musâwah (egalitarian), ashshidqu wal amânah (kejujuran dan tanggung jawab). Prinsip-prinsip tersebut, sebetulnya merupakan inti semangat makna demokrasi dan tentu hal itu bisa dibaca pada kitab alQur'an. Meskipun al-Qur'an tidak menyebut suatu bentuk dan sistem ketata-negaraan secara sharih (jelas), tatanan sistem demokrasi yang saat itu dan sekarang menjadi primadona bentuk demokrasi negara-negara di dunia, memiliki titik temu dan relevansi kuat untuk mewujudkan proses demokrasi di segala aspek kehidupan (Thompson, 2000, hlm.47-90). Dengan demikian, dalam Islam sebetulnya telah tertanam beberapa prinsip pokok dan tata nilai berkaitan dengan kehidupan masyarakat dan bernegara untuk menunjang lajunya proses demokrasi (Haikal, 1963, hlm. 35-37).

Kedua, adalah dari sisi praktis-historis. Maksudnya adalah, bahwa selain Islam di Indonesia telah meletakkan prinsip-prinsip demokrasi, dalam prakteknya Islam juga telah membuktikan nilai-nilai tersebut. Dalam sejarah (historis) di Indonesia, para pemimpin Muslim yang mewakili mayoritas bangsa, telah memainkan peran penting dalam menentukan reformasi sosial dan politik. Bila era Orde Lama para pemimpin Muslim berperan melalui Masyumi, maka pada pasca lengsernya lengsernya Suharto, dua organisasi Islam terbesar NU dan Muhammadiyah secara proaktif terlibat langsung dalam proses perubahan kepemimpinan untuk membangun sistem demokrasi di Indonesia. Kebudayaan sebagai modal sosial untuk membangun politik yang didasarkan pada normanorma demokrasi, dan ketulusan untuk menjadi seorang pemimpin yang selalu siap mengakomodasi aspirasi rakyat. Karena bangsa ini sudah lama merasakan ketidak tulusan pada masa rezim Soeharto, rakyat selalu di bohongi untuk melanggengkan kekuasaannya (status quo). Budaya feodal yang menempatkan relasi antara negara dengan rakyat sebagai patron clien (hubungantuan dan majikan) dengan 'penindasan struktural' yang dilakukan oleh negara agar rakyat tunduk dan patuh terhadap kebijakan-kebijakan yang dikeluarkan oleh negara, serta tidak ada ruang kebebasan untuk berekspresi dan aktualisasi diri, harus kita dekonstruksi dengan nilai-nilai kesejajaran.

Menurut Nurcholish Madjid (1999, 55-57), perlambangan demokrasi adalah pemilihan umum yang bebas dan pemberian suara yang rahasia. Hal ini benar-benar dapat dimengerti, karena hak untuk memberi suara secara bermakna dan bebas dari paksaan merupakan metafor untuk sistem politik yang membuka partisipasi rakyat umum. Tetapi demokratisasi tidaklah bersemayam dalam pemilu-pemilu. Jika demokrasi sebagaimana dipahami dinegeri maju harus punya "rumah", maka rumahnya adalah civil society atau masyarakat madani. Sekalipun konsep tentang civil society tidak dapat dianalisis secara persis, berfungsinya civil society jelas dan tegas ada dalam inti sistem politik yang membuka partisipasi rakyat umum.

Banyak yang mengatakan bahwa ikon kecenderungan gelobal demokrasi ialah ikon kecenderungan global demokratisasi ialah civil society. Walaupun begitu civil society 
p-ISSN: $1858-3237$

e-ISSN: 2623-0178

tidaklah menumbangkan pemerintahan, yang jika dilanda koropsi merajalelah di kalangannya sendiri dan kehilangan pijakan legitimasinya, biasanya tumbang dari dalam. Civil society lebih merupakan penerimaan manfaat ketimbang sebagai kekuatan penghancur. Lebih dari itu, civil society sering diedialisasikan sebagai suatu kebaikan sempurna. Sama halnya dengan semua gejala sosial, civil society dapat dan sering mempunyai sisi buruk. Sikap mementingkan diri sendiri, perasangka dan kebencian tidak jaran berjalan seiring dengan alturisme, sikap adil dan santun. Kiprah civil society yang bebas dan terkadang bukanlah suatu gagasan yang harus disambut hangat, melainkan pikiran yang sungguh mengerikan. Setiap chaos akan mudah menjadi dasar pembenaran tampilnya orang yang kuat yang hendak mengatasinya. Sehingga civil society dengan kiprah bebas dan tak terkendali akan justru akan menciptakan lawannya sendiri, yaitu otoritarisme seorang kuat. Dikalangan para ulama terkenal dengan ungkapan bijak, kebebasan seseorang terbatas oleh kebebasan orang lain.

\section{Faktor Penghambat}

Adapun faktor penghambat dalam penerapan prinsip-prinsip demokrasi Islam di Indonesia dalam rentang waktu masa orde baru adalah sebagai berikut:

Pertama, kekuasaan otoriter dari pemerintahan Soeharto. Dalam menerapkan prinsip-prinsip Islam tentang demokrasi sebagaimana yang dikemukakan oleh Nurcholish Madjid pada masa orde baru adalah adanya kekuasaan otoriter dari penguasa orde baru. Sebagaimana yang dikemukakan oleh Agussalim Sitompul (2008: hlm. 197) bahwa kalau orde baru, termasuk Soeharto dan para pemimpin orde baru mengecam demokrasi terpimpin ala Soekarno, dimana Soekarno menjadi presiden selama 22 tahun, tetapi mengapa kelakuan Soekarno itu di praktekkan oleh Suharto malah menjabat presiden selama 32 tahun, lebih lama 10 tahun dari Soekarno. Bedanya memang ada. Kalau masa Soekarno tidak pernah dilakukan pemilihan presiden, terus berlangsung selama 22 tahun dengan alasan revolusi belum selesai. Malahan oleh MPRS tahun 1963, Soekarno ditetapkan sebagai presiden seumur hidup. Masa Soeharto memang dilakukan pemilihan umum lima tahun sekali, dengan calon tunggal Soeharto. Ia sama saja sekali tiga uang. Soekarno dan Soeharto ingin berkuasa terus seumur hidup.

Lebih lanjut dijelaskan oleh Agussalim Sitompul (2008: hlm. 197) bahwa sejak tahun 1971 berturut-turut diadakan pemilihan umum, masing-masing berselang 5 tahun sekali yaitu; pemilu 1971, 1976, 1982, 1987, 1992, dan 1997 sebanyak 6 kali dengan terbentuknya DPR dan MPR baru sebagai produk pemili, maka ditetapkanlah GBHN baru yang sekaligus menjadi rencana pembangunan 5 tahun (replelita) dan juga memilih presiden baru. Repelita pertama pada masa orde baru ditetapkan 1 April 1969 kemudian pemilihan presiden dilaksanakan pada setiap sidang MPR. Akan tetapi anehnya, untuk calon presiden yang diajukan Badan Pekerja MPR hanya satu orang tidak boleh lebih. Begitujuga calon wakil presiden hanya satu orang, hanya saja setiap sidang calon wakil presiden berganti-ganti yaitu yang dapat bekerjasama dengan presiden dan tentunya sudah direstui oleh presiden terpilih. Adapun calon presiden hanya bole satu dan orangnya tetap pada setiap pemilihan presiden yaitu Soeharto. Jadi selama 32 tahun orde baru, walaupun 
diadakan pemilu setiap lima tahun, selalu Soeharto menjadi calon tunggal presiden. Semestinya selama 32 tahun orde baru sudah ada 6 orang presiden Republik Indonesia.

Dari beberapa penjelasan sebelumnya dapat dipaami bahwa kekuatan pemerintahan Soeharto begitu kuat dan kokoh, sehingga tidak memungkinkan adanya kelompok oposisi yang mengontrol jalannya pemerintaan.

Kedua, pembatasan partai politik dan dwi fungsi ABRI. Untuk memperkuat kekuasaan otoriternya maka pemerintaan orde baru melakukan pembaharuan dalam bidang politik, dengan cara menyederhanakan eksistensi partai politik bagaimana dikemukakan oleh Agussalim Sitompul (2008: hlm. 198) bahwa pembaharuan politik yang dilakukan oleh pemerintah orde baru secara mendasar meliputi tiga hal; yaitu; 1) Perubahan orientasi pembangunan dari orientasi idiologi ke orientasi program. 2) Penyederhanaan partai, dari 9 partai dan satu Golongan Karya, menjadi dua partai dan Golkar. 3) Pembaharuan dibidang idiologi, yaitu seluruh partai dan organisasi kemasyarakatan harus berasaskan pancasila. Wujud dari penyederhanaan partai itu, pertama, bergabungnya empat partai Islam, yaitu Partai NU, Partai Muslimin Indonesia, PSII dan Perti menjadi Partai Persatuan Pembangunan (PPP) tanggal 5 Januari 1973. Kedua, Bergabungnya lima partai yang berorientasi Nasional, Kristen dan Sosialis yaitu; PNI, IPKI, Parkindo, Partai Katolik Republik Indonesia, dan Murba menjadi Partai Demokrasi Indonesia (PDI) tanggal 10 Januari 1973. Ketiga, Golongan Karya yang semula bernama Sekretariat Bersama (Sekber) Golkar yang didirikan di Jakarta 24 Oktober 1964. Sejak pemilu 1971, Golkar sudah ikut pemilu. Penyederhanaan partai ini dituangkan dalam Undang-Undang No 3/1985, tentang Partai dan Golongan Karya. Sedangkan kewajiban partai dan ormas berasaskan Pancasila dituangkan dalam Undang-Undang No 8/1985 tentang Organisasi Kemasyarakatan.

Selain pembaharuan politik, untuk memperkokoh kekuasaan otoriter pemerintah orde baru, Presiden Soeharto memperkuat dwi fungsi ABRI, sehingga kekuasaan pemerintah tidak tergoyahkan. Dwi fungsi ABRI disebabkan karena secara historis, ABRI mempunyai peranan dalam memperjuangkan kemerdekaan dan menjaga keamanan serta kedaulatan negara, sehingga ABRI diberi kedudukan khusus, sehingga selain sebagai ABRI, merekapun menduduki berbagai jabatan penting dalam berbagai instansi pemerintah baik pusat maupun daerah seperti; Gubernur, Bupati, Wali Kota, Anggota DPR, DPRD, Duta Besar dan lain-lain.

Disatu pihak Dwi fungsi ABRI ini banyak diprotes dan dikeritik oleh masyarakat. Masalah dwi fungsi ABRI ini baru berakhir dalam sidang MPR tahun 1999, dan dilaksanakan secara bertahap serta dituntaskan tahun 2004. Menurut Agussalim Sitompul (2008:hlm. 198) bahwa ABRI merupakan tulang punggung yang kuat bagi keberlangsungan pemerintahan orde baru dalam jangka waktu yang lama. Selain itu, pemerintahan orde baru juga ditopang oleh Golkar sebagai partai pemerintah, sehingga seluruh pegawai negeri sipil harus menjadi anggota Golkar. Disiplin monoloyalitas diterapkan, sehingga pegawai negeri tidak boleh menjadi anggota partai. Hal ini jelas akan mengundang kecemburuan. Kemudian eksistensi Golkar baik dipusat maupun daerah selalu ditunjang dan dibantu sepenuhnya oleh ABRI. Ketimpangan politik ini sengaja dibuat oleh pemerintah orde baru agar Golkar dalam setiap pemilu bisa menang. 
Kenyatataan ini berlangsung selama pemerintahan orde baru. Dominasi Golkar dan ABRI ini baru berakhir setelah lengsernya Presiden Soeharto pada tahun 1998.

Disamping itu, faktor penghambat lain adalah adanya budaya politik yang masih sebatas "politik tanding" yang terus menerus mengadu kekuatan antara kelompok yang satu dengan kelompok yang lain dan melakukan segala cara untuk merebut kekuasaan atau terus mencari celah-celah kelemahan, kecacatan, keburukan, kekurangan dan kesalahan pemimpin yang sudah terpilih, untuk kemudian menjatuhkannya, dan bukan membangunnya ke arah yang lebih baik. Lihat saja ketika masa kampanye partai politik, tak jarang mereka saling menghujat, mencemooh dan mencari titik kelemahan partai politik lain. Singkatnya, partai-partai tersebut terus menjadi kekuatan-kekuasan oposan bagi partai yang menang dalam pemilihan. Jelas bahwa oposisi terdiri dari kekuatankekuatan politik yang heterogen, dan bagaimanapun alamiahnya hal ini menciptakan persoalan dalam pencapaian kohesi kesatuan aksi. Terlepas dari aspek ideologisnya, heterogenitas ini mencerminkan ketegangan antara dua orientasi strategi yang pada prinsipnya komplementer, tetapi dalam prakteknya sulit dikombinasikan. Sialnya lagi, oposisi ini saling menarik keuntungan politik bagi dirinya, dan bukan bagi kepentingan oposisi keseluruhan. Hal yang tidak kalah penting adalah, relasi negara-masyarakat harus berjalan secara sinergis yang termasuk di dalamnya civil society dan political society. Sinergitas ini merupakan indikator bahwa relasi tersebut tidak didasarkan pada unsur dominasi-subornasi, namun pada karakter equality (kesejajaran). Meskipun pada aras lokal, kualitas pendidikan politik masyarakat tidak bisa dijadikan sebagai tiang penyangga terciptanya konsolidasi demokrasi, namun setidaknya dengan sinergitas tiga elemen di atas, paling tidak kita mempunyai secercah harapan terhadap bangunan demokrasi di Indonesia.

Yang lebih penting disini adalah konsolidasi tidak hanya sekedar komitmen pada demokrasi secara abstrak, bahwa demokrasi "pada prinsipnya" adalah bentuk terbaik pemerintahan. Agar demokrasi terkonsolidasi, para elite, organisasi dan massa, sepenuhnya harus percaya bahwa sistem politik yang mereka miliki di negara mereka ini banyak dipatuhi dan dipertahankan. Legitimasi yang kokoh ini meliputi komitmen normatif dan prilaku bersama pada aturan dan praktik-praktik khusus dari sistem konstitusional negara tersebut atau disebut dengan "loyalitas" demokrasi. Sebagaimana yang saya uraian di atas, bahwa masyarakat setidaknya dapat berfungsi sebagai dialectic of control terhadap kekuasaan negara yang didudukkan secara seimbang untuk membangun kultur yang demokratis. Kesepakatan bersama juga ditempuh melalui representasi rakyat yang terjelma pada lembaga negara yang memiliki otoritas untuk mewakili masyarakat. Prinsip imperatif normatif tersebut bila dicerminkan pada kondisi obyektif era transisi di Indonesia menunjukkan bahwa usaha menuju demokrasi terkonsolidasi bukanlah hal yang mudah.

\section{E. Faktor Pendukung}

Sedangkan faktor pendukung dalam penerapan prinsip-prinsip demokrasi Islam di Indonesia dalam rentang waktu masa orde baru adalah sebagai berikut:

Pertama, munculnya kesadaran intelektual muslim tentang kehidupan beragama dan berbangsa. Menurut Nurcholish Madjid yang dikutif oleh Agussalim Sitompul (2008: hlm. 205) bahwa selama ini walaupun terjadinya ledakan sarjana Islam, tetapi mereka lebih 
banyak mengurusi masalah domistik atau masalah interen organisasi dalam tubuh umat Islam, sehinnga dalam dasarwarsa tahun 1970 dampak sosial mereka belum terasa dan memberi arti dalam kehidupan bermasyarakat, berbangsa dan bernegara. Dampak ledakan sarjana Islam tersebut baru terasa pada dasawarsa tahun 1980, karena urusan domistk sudah selesai dan mulai aktif keluar. Hasilnya sangat mengagungkan, dengan adanya semarak kebangkitan Islam disemua lapangan hidup. Dampak itu tanpak semakin besar karena adanya kemerdekaan umat Islam untuk bergerak secara longgar ketimbang masa sebelumnya, yang dirintangi dengan berbagai pagar politik yang meyakitkan dan menyebalkan. Karena sejak saat itu, umat Islam tidak lagi dimonopoli oleh mereka yang kebetulan menjadi anggota partai politik Islam. Akan tetapi kini Islam telah menjadi milik nasional yang meliputi sekitar $90 \%$ dari penduduk Indonesia. Seluruh bangsa mulai berkepentingan kepada Islam sebagai Rahmatan Li al-alamin mulai dirasakan.

Perlu disadari, gejala kebangkitan Islam pada tahun 1990, diliputi suasana antusiasme semangat yang tinggi, apalagi setelah berdirinya Ikatan Cendikiawan Muslim Indonesia (ICMI) bulan Desember 1990. ICMI dirancang untuk menyalurkan aspirasi umat kaum intelektual muslim seraya menyokong mereka agar berpartisipasi aktif, positif dan konstruktif dalam pembangunan nasional.

Menurut Agussalim Sitompul (2008:hlm. 206-207) bahwa kehadiran ICMI ditengah pergulatan politik di Indonesia, telah membawa presiden Soeharto untuk memberi kepercayaan yang luas kepada anggota-anggota ICMI duduk dalam berbagai jabatan di pemerintahan antara lain seperti menteri dan wakil presiden yaitu Habibi sebagai Ketua Umum ICMI pusat.

Kedua, munculnya gerakan reformasi tahun 1988. Tuntutan reformasi di Indonesia secara kongkrit sudah dikumandangkan sejak tahun 1995. Tutntutan reformasi tersebut baru terjadi tahun 1988, yang ditandai adanya penyerahan jabatan presiden dari Soeharto kepada wakil presiden BJ. Habibi yang otomatis menjadi presiden penuh. Ketika Habibi tampil sebagai presiden, masalah demokrasi menjadi agenda pertama yang ditegakkan. Kebebasan pers yang selama ini dibatasi menjadi terbuka. Partai-partai berdiri laksana cendawan di musim hujan tentang asas partai diberi kebebasan. Jumlah partai yang lolos ikut pemilu tahun 1999 sebanyak 48 partai, dan golkar menjadi partai golkar.

Menurut Agussalim Sitompul (2008: hlm. 218) bahwa gelombang reformasi yang melanda bangsa Indonesia sejak tahun 1998, telah mendorong perubahan dan penataan dalam aspek kehidupan berbangsa. Gerakan reformasi yang dimotori oleh mahasiswa, mempunyai arti penting terhadap perbaikan kehidupan bermasyarakat, berbangsa dan bernegara. Berbagai tuntutan muncul, antara lain misalnya tuntutan agar birokrasi dibersihkan dari koropsi, kolusi dan nepotisme ini telah mendorong usaha-usaha perbaikan dalam kehidupan demokrasi pemerintahan. Tidak ketinggalan muncul pula tuntutan agar otonomi daerah yang lebih luas dilakukan.

Selain ketiga hal di atas, faktor pendukung lainnya adalah sebagaimana dikemukakan oleh Nurcholish Madjid (1995, hlm.56), bahwa dalam proses penerapan demokrasi dinegeri kita adalah perlu adanya dorongan untuk menerapkan perwujudan nilai-nilai demokrasi tersebut secara konsisten. Dengan kata lain, bagaimana melaksanakan 
prinsip-prinsip demokrasi tersebut, sehingga benar-benar menjadi pandangan hidup nyata dalam kehidupan sehari-hari.

Selain itu, menurut Nurcholish Madjid (1995, hlm.57-58), ada beberapa hal yang berhubungan dengan demokrasi sebagai cara hidup, yaitu: pertama, pentingnya kesadaran kemajemukan. Ini tidak saja sekedar pengakuan (pasif) akan kenyataan masyarakat yang majemuk. Lebih dari itu, kesadaran akan kemajemukan menghadapi tanggapan yang positif terhadap kemajemukan itu sendiri secara aktif. Seseorang akan dapat menyesuaikan dirinya pada cara hidup demokratis jika ia mampu mendisplin dirinya kearah jenis persatuan dan kesatuan yang diperoleh melalui penggunaan kreatif dari dinamika dan segisegi positif kemajemukan masyarakat. Masyarakat yang teguh berpegang pada pandangan hidup demokratis harus dengan sendirinya juga teguh memelihara dan melindungi lingkup keanekaragaman yang luas. Pandangan hidup demokratisasi seperti ini menuntut moral pribadi yang tinggi.

Kedua, dalam peristilahan politik kita dikenal "musyawarah". Keinsafan akan makna dan semangat musyawarah menghendaki atau mengharuskan adanya keinsafan dan kedewasaan untuk dengan tulus menerima kemungkinan kompromi atau bahkan kalah suara. Semangat musyawarah menuntut agar setiap orang menerima kemungkinan terjadinya pandangan dasar bahwa belum tentu dan tidak harus, seluruh keinginan atau pikiran seseorang atau kelompok akan diterima dan dilaksanakan sepenuhnya. Korelasi prinsip itu adalah kesediaan untuk memungkinkan menerima bentuk-bentuk tertentu kompromi. Korelasinya yang lain adalah seberapah jauh kita dewasa dalam mengemukakan pendapat, mendengarkan pendapat orang lain, menerima perbedaan pendapat, dan kemungkinan mengambil pendapat yang lebih baik. Dalam masyarakat yang belum terlatih benar untuk demokrasi sering terjadi kejemuhan antara mengeritik yang sehat dan bertanggung jawab dan menghina yang merusak dan tanpa tanggung jawab.

Ketiga, ungkapan "tujuan menghalalkan cara" mengisyaratkan suatu kutukan kepada orang yang berusaha meraih tujuannya dengan cara-cara yang tidak peduli kepada pertimbangan moral. Pandangan hidup demokratis mewajibkan adanya keyakinan bahwa cara haruslah sesuai dengan tujuan. Bahkan sesungguhnya klaim atas, suatu tujuan yang baik harus diabsahkan oleh kebaikan cara yang ditempuh untuk meraihnya. Seperti yang dikemukakan oleh Albert Camus, "Indeed the and justifies the means. But what justifies the and? The means!" maka antara keduanya tidak boleh ada pertentangan. Setiap pertentangan antara cara an tujuan, jika telah tumbuh mengejalah cukup luas, pasti akan mengundang reaksi-reaksi yang dapat menghancurkan demokrasi. Maka demokrasi tidak terbayang tanpa akhlak yang tinggi.

Contoh akhlak yang seperti itu adalah sikap kesatria Sultan Saladin Shalahuddin alAyyubi yang melindungi perajurit dikalangan musuhnya, tentara salib yang kesasar ke kemahnya dalam keadaan luka parah kemudian diobatinya (dengan merahasiakan rapatrapat siapa sebenarnya dirinya sebagai komandan tentara Islam) dan setelah sembuh dilepaskan dengan aman. Sikap seperti ini jelas sekali memerlukan tingkat kepercayaan diri yang tinggi, yang membebaskan seseorang atau kelompok dari kekhawatiran yang berlebihan dan sebagai konsekuensi, kecurigaan dan prasangka juga yang berlebihan. 
Keempat, pemufakatan yang jujur dan sehat adalah hasil akhir musyawarah yang jujur dan sehat. Suasana masyarakat demokratisasi dituntut untuk menguasai dan menjalankan seni permusyawaratan yang jujur dan sehat guna mencapai pemufakatan yang juga jujur dan sehat pula. Pemufakatan yang dicapai melalui manipulasi atau taktiktaktik yang sesungguhnya hasil sebuah konspirasi, buka saja merupakan pemufakatan yang curang, cacat atau sakit malah dapat disebut sebagai penghianatan pada nilai dan semangat demokratik. Karena itu, faktor ketulusan dalam usaha bersama mewujudkan tatanan sosial yang baik untuk semua merupakan hal yang sangat pokok. Faktor ketulusan itu, seperti telah disinggung, mengandung makna pembebasan diri dari yang sempit. Prinsip ini pun terkait dengan paham musyawarah seperti telah dikemukakan di atas, musyawarah yang benar dan baik hanya akan berlangsung jika masing-masing pribadi atau kelompok yang bersangkutan mempunyai kesediakan psikologis untuk melihat kemungkinan orang lain benar dan diri sendiri salah, dan bahwa setiap orang pada dasarnya baik berkecenderungan baik dan beritikat baik.

Kelima, dari sekian banyak unsur kehidupan bersama yang baik adalah terpenuhinya keperluan pokok, yaitu pangan, sandang dan papan. Warga masyarakat demokratis ditantang untuk mampu menganut hidup dengan pemenuhan kebutuhan secara berencana, dan harus memiliki kepastian bahwa rencana-rencana itu benar-benar sejalan dengan tujuan praktek demokrasi.

Keenam, kerjasama antar warga masyarakat dan sikap saling mempercayai itikat baik masing-masing, kemudian jalinan dukung mendukung secara fungsional antara berbagai unsur kelembagaan kemasyarakatan yang ada, merupakan segi penunjang efesiensi untuk demokrasi. Masyarakat yang terkotak-kotak dengan masing-masing pencurigaan kepada lainnya bukan saja mengakibatkan tidak efisiensinya cara hidup demokratis, tetapi juga dapat menjurus kepada lahirnya polah tingkah laku yang bertentangan dengan nilai-nilai demokrasi. Pengakuan akan kebebasan rohani, persamaan hak dan kewajiban bagi semua, dan tingkah laku penuh percaya pada itikat baik orang dan kelompok lain mengharuskan adanya landasan pandangan kemanusiaan yang positip dan optimis. Pandangan kemanusiaan yang negatif dan pesimistis akan dengan sindirinya sulit menghindari dengan perilaku curiga dan tidak percaya kepada sesama manusia, yang kemudian ujungnya ialah keenganan bekerjasama.

Ketujuh, dalam keseharian, kita biasa berbicara tentang pentingnya pendidikan demokratis, tetapi karena pengalaman kita yang belum pernah dengan sungguh-sungguh menyaksikan dan apalagi merasakan hidup berdemokrasi ditambah kenyataan bahwa demokrasi dalam abad ini masih terbatas pada usaha indoktrinasi dan penyuapan pada konsep-konsep secara verbalistis. Kejengkelan yang sering terdengar dalam masyarakat tentang adanya kesenjangan tentang antara apa yang dikatakan adalah akibat dari kuatnya budaya mengurui dalam masyarakat kita. Sehingga verbalisme yang dihasilkannya juga menghasilkan kepuasan tersendiri dan membuat yang bersangkutan merasa telah berbuat sesuatu hanya karena telah berbicara. 


\section{Penutup}

Prinsip-prinsip Islam tentang demokrasi dalam pemikiran Nurcholish Madjid meliputi: adanya musyawarah (syura), keadilan (al-'adalah), kesetaraan (al-musawah), kepercayaan (al-amanah), tanggung jawab (al-mas'uliyyah) dan kebebasan (al-hurriyyah) yang harus ditopang oleh adanya kebersamaan, plururalisme, nilai-nilai akhlakul karimah, kejujuran dan proses penerapan prinsip-prinsip demokrasi secara terus menerus sampai mencapai kesempurnaan.

Implementasi prinsip-prinsip Islam tentang demokrasi dalam pemikiran Nurcholish Madjid pada percaturan politik di Indonesia kurun waktu tahun 1970-2005 masih belum dapat diterapkan, hal ini disebabkan oleh kuatnya cengkraman kekuasaan penguasa orde baru dan terbentuknya keseragaman politik serta sosial kemasyarakatan melalui kesamaan asas parpol dan organisasi kemasyarakatan serta keagamaan. Padahal menurut Nurcholish Madjid umat Islam Indonesia telah memiliki modal dasar yang kuat, yaitu ajaran Islam yang mengandung nilai-nilai universal terutama tentang demokrasi, adanya UUD 1945 dan Pancasila sebagai sumbangan umat Islam, serta dukungan mayoritas umat Islam teradap keberlangsungan sistem negara demokrasi.

Faktor pendukung dalam menerapkan prinsip-prinsip Islam tentang demokrasi di Indonesia menurut Nurcholish Madjid, yaitu adanya kebangkitan kesadaran kaum intelektual Islam tentang pentingnya ajaran agama dalam kehidupan berbangsa dan bernegara di Indonesia. Terjadinya gerakan reformasi yang menumbangkan rezim orde baru, sehingga memungkinkan terjadinya perubahan mendasar dalam kehidupan berdemokrasi di Indonesia, seperti munculnya kebebasan pers yang menjadi kontrol bagi penyelenggaraan kehidupan berbangsa dan bernegara. Sedangkan faktor yang penghambat adalah adanya kekuasaan otoriter penguasa orde baru, Dwi Fungsi ABRI, budaya politik yang masih sebatas politik tanding, dan umat Islam masih mudah di adu domba.

\section{Daftar Pustaka}

Al-Mawardi, Abu Hasan Ali bin Muhammad bin Habib al-Bashri, Ttp. al-Ahkam asSultaniyyah. Beirut; Dar al-Fikr.

Al-Maududi, A'la, Abdul. 1985. Hak Asasi Manusia Dalam Islam. Bandung: Penerbit Pustaka.

Enayat, Hamid. 1981. Reaksi Politik Sunni Syi’ah. Bandung: Pustaka.

Kementerian Agama RI 2011. Al-Qur'an (Transliterasi Arab-Latin dan Tejemahnya. Bandung Fokus Media.

Majid, Nurcholish 1982. Islam Di Indonesia: Tantangan dan Peluang, dalam Cyriac K.

Majid, Nurcholish 1982. Khazanah Intelektual Islam. Jakarta, Bulan Bintang.

Madjid, Nurcholis 1984. Khazanah Intelektual Islam. Jakarta: Bulan Bintang. 
Majid, Nurcholis 1985. Lebih Jauh Dengan Nurcholis Madjid, wawancara dengan Sudirman Tebba, Budiarto Danujaya, dan H. Azkarmin Zaini dari Harian Kompas tanggal 3 November.

Majid, Nurcholish 1987. Islam, Kemoderanan dan Keindonesiaan. Bandung: Mizan.

Majid, Nurcholish 1992. Islam, Doktrin dan Peradaban, Jakarta. Paramadina.

Majid, Nurcholish 1993. Islam, Kerakyatan dan KeIndonesiaan. Bandung: Mizan

Majid, Nurcholish 1994. Pintu-Pintu Menuju Tuhan. Jakarta, Paramdina.

Majid, Nurcholish 1995. Islam, Agama Kemanusiaan. Jakarta, Paramadina.

Majid, Nurcholish 1995. Islam, Agama Peradaban. Jakarta, Paramadina.

Majid, Nurcholish 1996. "In Search of Islamic Roots for Modern Pluralism: The Indonesian Experiences" dalam Mark Woodward ed., Toward a new Paradigm, Recent Developments in Indonesian Islamic Thoughts Tempe, Arizona: Arizona State University.

Majid, Nurcholish 1997. Dialog Keterbukaan. Jakarta, Paradima.

Majid, Nurcholish 1999. Cendekiawan dan Religious Masyarakat. Jakarta: Paramadina.

Majid, Nurcholish 2010. Api Islam. Jakarta, Kompas.

Munjani, Saiful. 2007. Muslim Demokrat: Islam dan Budaya Demokrasi dan Partisipasi Politik di Indonesia Pasca Orde Baru. Jakarta: Gramedia Pustaka Utama.

Nurtjahyo, Hendra. 2006. Filsafat Demokrasi. Jakarta: Bumi Aksara.

PP Muhammadiyah t.th. Muhammadiyah Movement in Indonesia. Yogyakarta, Indonesia.

Sitompul, Agussalim 2008. Usaha-Usaha Mendirikan Negara Islam dan Pelaksanaan Syariat Islam di Indonesia. Jakarta: Misaka Galiza.

Sitompul, Agussalim. 2008. Menyatu dengan Umat Menyatu dengan Bangsa Pemikiran Ke Islaman-Ke Indonesiaan HMI (1947-1997). Jakarta: Misaka Galiza.

Zainuddin, M 2011. Islam dan Demokrasi. Yayasan Abad Demokrasi Edisi. 005.

online journals http://jurnal.radenfatah.ac.id/index.php/medinate 